\title{
Nutritional Efficiency and Morphophysiological Aspects With Growth in the 'Okinawa Roxo' Peach Rootstock
}

\author{
Aline das G. Souza ${ }^{1}$, Cristina W. Ritterbusch ${ }^{1}$, Renata D. Menegatti ${ }^{1}$, Oscar J. Smiderle ${ }^{2} \&$ Valmor J. Bianchi $^{1}$ \\ ${ }^{1}$ Federal University of Pelotas, Capão do Leão, RS, Brazil \\ ${ }^{2}$ Brazilian Agricultural Research Corporation, Boa Vista, RR, Brazil \\ Correspondence: Renata D. Menegatti, Institute of Biology, Department of Botany, Federal University of Pelotas, \\ Campus Universitário, S/N., Caixa Postal 345, 96010-900 Capão do Leão, RS, Brazil. Tel: 55-959-9904-6104. \\ E-mail: renata.d.menegatti@gmail.com
}

Received: March 30, 2019

Accepted: April 30, 2019 Online Published: June 30, 2019

doi:10.5539/jas.v11n9p221

URL: https://doi.org/10.5539/jas.v11n9p221

\begin{abstract}
The aim of this study was to evaluate the efficiency of nutrient uptake, accumulation, distribution and use, and its relationship with growth variables, chlorophyll content, and root and shoot dry-weight partitioning in the 'Okinawa Roxo' peach rootstock, submitted to different nutrient solutions and substrates. The experimental design was completely randomised, with four treatments and five replications. The treatments were T1: Ns1 = Souza et al. nutrient solution (2011), applied to a sand substrate; T2: Ns2 = Hoagland and Arnon (1950), applied to a sand substrate; T3: Commercial Substrate $+\mathrm{H}_{2} \mathrm{O}$; and T4: Control, Sand $+\mathrm{H}_{2} \mathrm{O}$. Ninety days after transplanting (DAT), morphological, physiological and nutritional parameters were determined in the 'Okinawa Roxo' rootstock, together with the correlation between nitrogen concentration and nitrogen balance index, and the chlorophyll content and index. The greatest zinc content was detected in the shoots of the 'Okinawa Roxo' plants, at more than $80 \%$ of the accumulated total. Treatments T1 and T2 (nutrient solutions Ns1 and Ns2 respectively) made it possible to obtain 'Okinawa Roxo' plants with the best morphophysiological characteristics, being ready for grafting three months after transplanting in a greenhouse. The use of the Ns1 nutrient solution resulted in greater efficiency in the uptake and use of the nutrients nitrogen $(\mathrm{N})$, potassium $(\mathrm{K})$ and iron $(\mathrm{Fe})$. The $\mathrm{N}$ and Total Chlorophyll concentrations in the leaves of the red-leaved peach tree can be estimated indirectly with a chlorophyll meter, and are an accurate indication of the nutritional status of the plant in relation to nitrogen content.
\end{abstract}

Keywords: Prunus persica, rootstocks, seedling production, nutrient partioning, mineral nutrition

\section{Introduction}

Brazil is one of the largest fruit producers in the world, with soil and climate characteristics suitable for the development of fruit farming using species of temperate, subtropical and tropical climates (Brazilian Fruit Yearbook, 2017). Thus, since the 1980s, there have been technological advances in plant production systems for several fruit species in the country (Pereira \& Kavati, 2011).

Due to this modernisation of the sector and the importance of plants quality in the success and profitability of the orchard, nurserymen have invested in production and management technology (Peticila et al., 2017; Granatstein et al., 2016), seeking to introduce the use of containers, new substrates, environments with plastic covering (Picolloto et al., 1997), irrigation systems, and organic (Reeve et al., 2017) and mineral fertilisers (Peticila et al., 2017), with the aim of producing rootstocks and grafted plants of high quality.

These advances contrast with the production of Prunus persica plants in Brazil, where according to Fischer et al. (2016), the traditional method of rootstock production still generally predominates, in which sowing is still carried out in the field, using a mixture of seeds of scion cultivars obtained from the peach-processing industry.

Faced with this scenario, several studies have sought to evaluate genotypes selected for use as rootstock, such as the studies carried by Fischer et al. (2016), Rocha et al. (2016), Almeida et al. (2015), and Mayer et al. (2015). However, there is still little knowledge of the nutritional requirements and the physiological and growth responses of plants of these genotypes in production systems in protected environments using different substrates and mineral fertiliser. 
Fertilising plants with nutrient solutions has been increasingly used in the nutritional management of fruit species, with a view to optimising the use of inputs and plant growth under different cropping systems (Pradeepkumar et al., 2017; Wang et al., 2017; Miloševic et al., 2013). Nutrient solutions also have a wide application in studies of plant physiology, with the aim of studying and correlating the presence and concentration of mineral nutrients with the processes that coordinate plant growth (Abrisqueta et al., 2011; Baldi et al., 2014).

In order for a plant to develop and express its maximum productive potential, the correct supply of nutrients through fertilisation is necessary (Savvas et al., 2017). Epstein and Bloom (2006) add that much effort has been invested in formulating nutrient solutions, but there is little information on the concentration and/or proportion of salts that would be suitable for all crops.

Hoagland and Arnon nutrient solution is the most commonly used for investigating nutritional problems in plants, and is the basis for the formulation of other commercial nutrient solutions (Marles, 2017). According to Souza et al. (2017) the use of a complete nutrient solution, as formulated by Souza et al. (2011), together with substrates, is a promising technique in the initial formation of peach rootstocks in a greenhouse.

An strategy for identifying the nutritional requirements of the species is to determine the concentration that would promote the best uptake, distribution and use of nutrients and their effects on growth variables (Elsadr \& Sherif, 2016; Baldi et al., 2014; Abrisqueta et al., 2011), the levels of photosynthetic pigments, and the effects of dry-weight partitioning on the mineral composition of the roots, stems and leaves of the plants (Zhu et al., 2017; Elsadr \& Sherif, 2016; Baldi et al., 2014).

There are no studies of the chemical and physiological attributes of the red-leaved cultivars of the peach tree found in the literature, and 'Okinawa Roxo' is a read leaf peach rootstock with great potential for use in Brazil (Souza et al., 2016; Souza et al., 2017), a fact which stimulated the development of the present study.

Accordingly, the aim of this study was to evaluate the efficiency of nutrient uptake, accumulation, distribution and use in rootstocks of the 'Okinawa Roxo' cultivar submitted to different nutrient solutions and substrates, as well as aspects of growth variables, photosynthetic pigment content and dry weight partitioning.

\section{Method}

Peach [Prunus persica (L.) Batsch] rootstock cultivar 'Okinawa Roxo', obtained from seeds, was used as plant material. Mature fruit was harvested, and the pulp immediately removed from the endocarp, which was dried in the shade after washing.

To obtain the plants, the endocarp was broken and the seeds stratified in moist cold at $7{ }^{\circ} \mathrm{C}$ for 21 days, as described by Picollotto et al. (2007). Sowing was then carried out in polystyrene trays of 72 cells $\left(114 \mathrm{~cm}^{3}\right.$ per cell), containing a substrate composed of soil + vermiculite + medium sand + Bioplant ${ }^{\circledR}$ commercial substrate $(1: 1: 1: 1)$, whose chemical composition is shown in Table 1.

Table 1. Chemical composition of the substrates used for the production of peach rootstocks

\begin{tabular}{|c|c|c|c|c|c|c|c|c|c|c|c|c|c|}
\hline Substrate & $\mathrm{OM}^{* *}$ & $\mathrm{~V}$ & $\mathrm{Al}$ & $\mathrm{H}+\mathrm{Al}$ & SB & CEC & $\mathrm{P}$ & $\mathrm{K}$ & $\mathrm{Ca}$ & $\mathrm{Mg}$ & $\mathrm{Zn}$ & $\mathrm{Fe}$ & Mn \\
\hline & \multicolumn{2}{|c|}{------- \% ------- } & \multicolumn{4}{|c|}{---------- $\mathrm{cmol}_{\mathrm{c}} \mathrm{dm}^{-3}$--------- } & \multicolumn{4}{|c|}{------------- mg dm ${ }^{-3}$------------ } & \multicolumn{3}{|c|}{------ $\mu \mathrm{g} \mathrm{dm}^{-3}$------ } \\
\hline $\mathrm{SS}^{*}$ & 2.12 & 78.00 & 0.01 & 1.00 & 1.83 & 1.78 & 1.89 & 7.80 & 0.42 & 0.10 & 1.62 & 5.12 & 3.12 \\
\hline Sand $^{* *}$ & 0.00 & 67.00 & 0.00 & 0.00 & 0.00 & 0.00 & 0.00 & 0.00 & 0.00 & 0.00 & 0.44 & 0.00 & 0.00 \\
\hline Bioplant $^{(\mathbb{2}}$ & 20.5 & 72.00 & 0.17 & 8.10 & 20.56 & 2.90 & 776.48 & 1.410 & 12.22 & 4.72 & 0.00 & 0.00 & 0.00 \\
\hline
\end{tabular}

Note. ${ }^{*} \mathrm{SS}=$ Substrate used when sowing $=25 \%$ soil $+25 \%$ vermiculite $+25 \%$ sand $+25 \%$ commercial substrate;

${ }^{* *} 100 \%$ sand; **OM: Organic Matter; V: Base saturation; SB: Sum of Bases; CEC: Cation Exchange Capacity.

The present study was conducted between September to December 2015 at dependences of Federal University of Pelotas (UFPel), in Capão do Leão, Brazil. The plants were kept on benches in a greenhouse at average temperatures ranging from $18{ }^{\circ} \mathrm{C}$ to $36^{\circ} \mathrm{C}$, night and day respectively. At 23 days after sowing, the seedlings had a mean height of $15 \pm 3 \mathrm{~cm}$, and were transplanted into plastic bags containing $2.5 \mathrm{~L}$ of the following substrates: a) $100 \%$ sand; b) $100 \%$ Bioplant ${ }^{\circledR}$ commercial substrate. The manually irrigated as needed with three weekly irrigations of $50 \mathrm{~mL}$ of the nutrient solutions shown in Table 2. 
Table 2. Chemical composition of the nutrient solutions described by Hoagland and Arnon (1950) and by Souza et al. (2011)

\begin{tabular}{lll}
\hline Nutrient & Hoagland \& Arnon & Souza \\
\hline----------------------------- \\
$\mathrm{N}$ & 210.01 & 223.8 \\
$\mathrm{P}$ & 31.0 & 61.9 \\
$\mathrm{~K}$ & 234.6 & 326.2 \\
$\mathrm{Ca}$ & 200.4 & 221.3 \\
$\mathrm{Mg}$ & 48.6 & 49.2 \\
$\mathrm{~S}$ & 64.2 & 68.7 \\
$----\mathrm{m}^{-1}$ & nutrient solution \\
$\mathrm{B}$ & 300 & 498 \\
$\mathrm{Cu}$ & 20 & 39 \\
$\mathrm{Fe}$ & 3022 & 5000 \\
$\mathrm{Mn}$ & 502 & 419 \\
$\mathrm{Zn}$ & 50 & 114 \\
\hline
\end{tabular}

The experimental design was completely randomised with four treatments and five replications of five plants each, giving a total of 25 plants per treatment. The experiment was unifactorial, comprising the following treatments: T1: Ns1 = nutrient solution Souza et al. (2011) applied to a substrate of medium sand; T2: Ns2 = Hoagland and Arnon (1950) applied to a substrate of medium sand; T3: $\mathrm{H}_{2} \mathrm{O}$ applied to Bioplant ${ }^{\circledR}$ commercial substrate; T4: Control, $\mathrm{H}_{2} \mathrm{O}$ applied to a substrate of medium sand. Every 15 days the 'Okinawa Roxo' plants were evaluated for height (using a millimeter rule) and stem diameter $(10 \mathrm{~cm}$ above the substrate, with the aid of digital callipers).

At 90 days after transplanting (DAT), the chlorophyll index (CHLI) and the nitrogen balance index (NBI) were determined using a Dualex chlorophyll meter. Between 09:00 and 11:00 each morning, measurements were taken on two completely expanded leaves located on the apical third of each plant. Immediately after taking the readings, the leaves were detached and placed in polystyrene boxes containing ice, and taken to the laboratory to determine the chlorophyll content. To do this, leaf discs were collected to make up a sample of approximately $1.5 \mathrm{~g}$ fresh weight, which was finely ground in $80 \%$ acetone in the absence of light. The extracts were filtered through filter paper and collected in $25 \mathrm{ml}$ volumetric flasks, and the volume topped up at the end of filtration. The supernatants were analysed with an Agilent UV-Vis spectrophotometer, readings being taken at $645 \mathrm{~nm}$ $\left(\mathrm{A}_{645}\right)$ and $663 \mathrm{~nm}\left(\mathrm{~A}_{663}\right)$ against a blank containing 80\% acetone. The chlorophyll $a$ and $b$, and the total chlorophyll content were calculated using the equations established by Arnon (1949).

The other variables evaluated at 90 DAT were the root and shoot dry weight, with the aim of assessing assimilate partitioning. The shoots and roots were separated and packed into paper bags, and placed in a drying oven at $70{ }^{\circ} \mathrm{C}$ for 72 hours. After drying, the samples were weighed on a $0.01 \mathrm{~g}$ precision balance to determine shoot dry weight (MSPA), root-system dry weight (RDW), and by summing these, the total dry weight of the plant (TDW). In order to measure the quality of the plants for use as rootstock, the formula proposed by Dickson et al. (1960) was used to define the Dickson Quality Index (DQI).

The roots and shoots were then ground in a Wiley mill with a 20-mesh screen, and the macro- and micronutrient concentrations were analysed as per Malavolta et al. (1997). The content of each nutrient was calculated by multiplying the dry weight of each part of the plant by the concentration of each nutrient (Bataglia et al., 1983). The following indices were also calculated: (a) uptake efficiency $=$ (total nutrient content of the plant $) /($ root-system dry weight), as per Swiader et al. (1994); (b) transport efficiency $=[$ (nutrient content of the shoots) $/$ (total nutrient content of the plant) $\times 100$, as per Li et al. (1991); (c) use efficiency $=$ (total dry matter produced $)^{2} /$ (total nutrient content of the plant), in macronutrients $\left(\mathrm{mg}\right.$ plant $\left.^{-1}\right)$ and micronutrients $\left(\mu \mathrm{g}\right.$ plant $\left.{ }^{-1}\right)$ respectively, as per Siddiqi and Glass (1981).

Possible differences among treatments were verified by analysis of variance (ANOVA). The variables that showed significant differences were submitted out Tukey's test at 5\% probability using the Sisvar software (Ferreira, 2011). Pearson correlation analysis was performed between the concentrations of nitrogen, chlorophyll $a$ and $b$, and total chlorophyll, the chlorophyll index and the nitrogen balance index, using the R software (2014). 


\section{Results and Discussion}

At 90 days after transplanting (DAT), the plants from treatment T1 (nutrient solution-Sn1) presented the highest mean values for height, reaching $123.0 \mathrm{~cm}$ (Table 3). In the production sector for peach tree plants, it is interesting that rootstocks show rapid growth in both height and stem diameter, since in Brazil grafting is performed almost exclusively by active budding or vegetative bud (Mayer et al., 2017). Stem diameter in particular determines whether the rootstocks are suitable for grafting as early as possible, and should be between 5.0 and $10 \mathrm{~mm}$ according to the production standards for peach rootstocks (Brazil, 2005).

Table 3. Mean values for height $(\mathrm{H}, \mathrm{cm})$, stem diameter $(\mathrm{SD}, \mathrm{mm})$, root-system dry weight (RDW, g), shoot dry weight (SDW, g), total dry weight (TDW) and Dickson quality index (DQI), determined in 'Okinawa Roxo' rootstocks under different forms of cultivation, at 90 days after transplanting

\begin{tabular}{lllllll}
\hline Treatment & $\mathrm{H}$ & SD & SDW & RDW & TDW & DQI \\
\hline T1 (Ns1)** & $123.0 \mathrm{a}^{*}$ & $7.33 \mathrm{a}$ & $53.94 \mathrm{a}$ & $20.28 \mathrm{a}$ & $74.22 \mathrm{a}$ & $4.89 \mathrm{a}$ \\
T2 (Ns2) & $93.6 \mathrm{~b}$ & $5.28 \mathrm{~b}$ & $42.18 \mathrm{~b}$ & $16.81 \mathrm{~b}$ & $58.99 \mathrm{~b}$ & $3.90 \mathrm{~b}$ \\
T3 & $64.0 \mathrm{c}$ & $4.28 \mathrm{c}$ & $28.38 \mathrm{c}$ & $10.81 \mathrm{c}$ & $39.19 \mathrm{c}$ & $3.52 \mathrm{~b}$ \\
T4 & $18.3 \mathrm{~d}$ & $1.97 \mathrm{~d}$ & $2.88 \mathrm{~d}$ & $1.64 \mathrm{~d}$ & $4.52 \mathrm{~d}$ & $1.79 \mathrm{c}$ \\
CV $(\%)$ & 3.71 & 8.62 & 12.89 & 11.91 & 11.30 & 9.92 \\
\hline
\end{tabular}

Note. *Mean values followed by the same letter in a column do not differ by Tukey's test ( $\mathrm{p} \leq 5 \%) .{ }^{* *} \mathrm{~T} 1(\mathrm{Ns} 1)$ Souza et al. nutrient solution (2011) in medium sand; T2 (Ns 2) Hoagland and Arnon solution (1950) in medium sand; T3 (Commercial substrate + water); T4 (Sand + water).

The mean stem diameter of the plants ranged from 1.97 to $7.33 \mathrm{~mm}$ (Table 3). The lowest mean value for stem diameter was obtained with treatment T4 $(1.97 \mathrm{~mm})$ followed by T3 $(4.28 \mathrm{~mm})$. Peach rootstocks suitable for grafting should have a minimum diameter of $5.0 \mathrm{~mm}$ (Brazil, 1984). Therefore, according to Brazil (1984), treatments $\mathrm{T} 3$ and $\mathrm{T} 4$ did not meet the required standards during this period.

In treatment $\mathrm{T} 1$ (Ns1), plant diameter was $41.61 \%$ greater than in treatment $\mathrm{T} 3$ (commercial substrate) (Table 3), demonstrating the importance of adequate nutrient application via nutrient solution in the production of rootstocks of the 'Okinawa Roxo' cultivar, regardless of the substrate used.

At 180 days after transplanting, Picolloto et al. (2007) recorded a mean height and diameter of $46.6 \mathrm{~cm}$ and 5.0 $\mathrm{mm}$ in 'Okinawa' and 'Capdeboscq' peach rootstocks respectively, grown in a greenhouse in plastic bags $(4.5 \mathrm{~L})$ containing commercial substrate (Plantmax ${ }^{\circledR}$ ). Commercial substrates have several compositions, and may contain coconut fibre, pine bark, manure, sawdust, vermiculite, rice husks, ash, agricultural gypsum, calcium carbonate, magnesium, magnesium thermophosphate (yoorin) and additives (fertilisers). Even when containing mineral elements in their composition, commercial substrates do not generally promote the satisfactory growth of peach rootstocks, possibly because the physiological and biochemical processes associated with plant growth and development are limited due to the reduced availability and rapid depletion of nutrients during the rapid growth phase.

Research to establish the best formulation of a nutrient solution suitable for all crops has intensified, with the aim of achieving high morphophysiological and nutritional quality (Furlani et al., 1999). These parameters were clearly seen in the present study, since the shoot dry weight (SDW), root-system dry weight (RDW) and total dry weight (TDW) of the 'Okinawa Roxo' plants showed the highest mean values with use of the Ns1 nutrient solution, followed by the Ns2 nutrient solution, even in an inert substrate such as sand (Table 3).

Differences were found between treatments for the macro- and micronutrient content, and were greater in both the shoots and roots of the plants from T1 (nutrient solution-Ns1) (Table 4), which is consistent with the greater increase in shoot and root dry weight of the plants (Table 3). Overall, T1 also resulted in better seedling quality, with a DQI of 4.89, superior to T2 and T3, which did not differ from each other (Table 3). 
Table 4. Mean values for macro- $\left(\mathrm{mg} \mathrm{plant}^{-1}\right)$ and micronutrients $\left(\mu \mathrm{g}\right.$ plant $\left.{ }^{-1}\right)$ in the shoots and root system, determined in 'Okinawa Roxo' rootstocks under different forms of cultivation, at 90 days after transplanting

\begin{tabular}{|c|c|c|c|c|c|c|c|c|c|c|c|}
\hline Treatment & $\mathrm{N}$ & $\mathrm{P}$ & $\mathrm{K}$ & $\mathrm{Ca}$ & $\mathrm{Mg}$ & $\mathrm{S}$ & $\mathrm{B}$ & $\mathrm{Cu}$ & $\mathrm{Fe}$ & $\mathrm{Mn}$ & $\mathrm{Zn}$ \\
\hline & \multicolumn{6}{|c|}{--------- macronutrient content mg plant ${ }^{-1}$--------- } & \multicolumn{5}{|c|}{------- micronutrient content $\mu \mathrm{g}_{\text {plant }}{ }^{-1}$-------- } \\
\hline \multicolumn{12}{|l|}{ Shoots ** } \\
\hline $\mathrm{T} 1$ (Ns1) & $414.11 \mathrm{a} *$ & $44.41 \mathrm{a}$ & $317.06 \mathrm{a}$ & $94.04 \mathrm{a}$ & $82.90 \mathrm{a}$ & $28.66 \mathrm{a}$ & $554.29 \mathrm{a}$ & $50.74 \mathrm{a}$ & $2280.58 \mathrm{a}$ & $666.18 \mathrm{a}$ & $430.33 \mathrm{a}$ \\
\hline $\mathrm{T} 2$ (Ns2) & $309.65 b$ & $30.96 b$ & $242.16 b$ & $74.19 \mathrm{~b}$ & $51.18 \mathrm{~b}$ & $16.85 b$ & $341.94 b$ & $34.10 \mathrm{~b}$ & $1806.65 b$ & $359.86 b$ & $196.82 b$ \\
\hline $\mathrm{T} 3$ & $198.28 \mathrm{c}$ & $21.00 \mathrm{c}$ & $181.55 \mathrm{c}$ & $15.13 \mathrm{c}$ & $23.95 \mathrm{c}$ & $6.68 \mathrm{c}$ & $95.98 \mathrm{c}$ & $16.00 \mathrm{c}$ & 414.01c & $45.17 \mathrm{c}$ & 144.91c \\
\hline $\mathrm{T} 4$ & $1.90 \mathrm{~d}$ & $1.82 \mathrm{~d}$ & $1.12 \mathrm{~d}$ & $0.85 \mathrm{~d}$ & $0.67 \mathrm{~d}$ & $0.27 \mathrm{~d}$ & $0.22 \mathrm{~d}$ & $0.62 \mathrm{~d}$ & $0.15 \mathrm{~d}$ & $0.25 \mathrm{~d}$ & $0.36 \mathrm{~d}$ \\
\hline$* * \mathrm{CV} \%$ & 14.17 & 12.9 & 13.82 & 13.45 & 13.7 & 13.4 & 14.14 & 13.2 & 13.74 & 13.86 & 13.97 \\
\hline \multicolumn{12}{|c|}{ Root system ** } \\
\hline T1 (Ns1) & $203.03 \mathrm{a}$ & $23.59 \mathrm{a}$ & $170.53 a$ & $51.64 \mathrm{a}$ & $57.31 \mathrm{a}$ & $19.37 \mathrm{a}$ & $217.69 a$ & $37.87 \mathrm{a}$ & $2607.97 a$ & $223.30 \mathrm{a}$ & $54.77 \mathrm{a}$ \\
\hline $\mathrm{T} 2$ (Ns2) & $151.28 \mathrm{~b}$ & $18.75 b$ & $103.55 b$ & $27.86 \mathrm{~b}$ & $28.79 b$ & $8.78 b$ & $158.83 b$ & $21.24 \mathrm{~b}$ & $1290.72 b$ & $228.53 b$ & $38.04 b$ \\
\hline $\mathrm{T} 3$ & $92.45 \mathrm{c}$ & $12.23 \mathrm{c}$ & $71.58 \mathrm{c}$ & $11.37 \mathrm{c}$ & $11.89 \mathrm{c}$ & $3.37 \mathrm{c}$ & $60.48 \mathrm{c}$ & $6.37 \mathrm{c}$ & $258.83 \mathrm{c}$ & $35.92 \mathrm{c}$ & $23.33 \mathrm{c}$ \\
\hline $\mathrm{T} 4$ & $3.26 \mathrm{~d}$ & $2.19 \mathrm{~d}$ & $2.71 \mathrm{~d}$ & $1.02 \mathrm{~d}$ & $0.80 \mathrm{~d}$ & $1.22 \mathrm{~d}$ & $1.16 \mathrm{~d}$ & $0.25 \mathrm{~d}$ & $0.23 \mathrm{~d}$ & $0.83 \mathrm{~d}$ & $0.22 \mathrm{~d}$ \\
\hline$* * * \mathrm{CV} \%$ & 10.38 & 8.36 & 9.98 & 10.27 & 10.01 & 11.15 & 10.01 & 10.40 & 10.45 & 10.83 & 10.41 \\
\hline
\end{tabular}

Note. Mean values followed by the same letter in a column do not differ by Tukey's test (p $\leq 5 \%)$. **T1 (Ns1); T2 (Ns2); T3 (Commercial substrate + water); T4 (Sand + water). Where, $\mathrm{N}=$ nitrogen; $\mathrm{P}=$ phosphorus; $\mathrm{K}=$ potassium; $\mathrm{Ca}=$ calcium; $\mathrm{Mg}=$ magnesium; $\mathrm{S}=$ sulphur; $\mathrm{B}=$ boron; $\mathrm{Cu}=$ copper; $\mathrm{Fe}=$ iron; $\mathrm{Mn}=$ manganese; $\mathrm{Zn}=$ zinc.

In general, the lowest macro- and micronutrient content was seen in treatments T3 and T4 (Table 4). Despite the plants from T3 having a low nutrient content in the shoots, there were no visual symptoms of leaf deficiency. It is possible that 'hidden hunger' was present with this treatment, characterised when plants are deficient in a specific nutrient without presenting visible symptoms, the deficiency being detrimental to plant growth (Meriño-Gergichevich et al., 2017). This was evidenced by the smaller growth of the 'Okinawa Roxo' plants in T3 when compared to T1 (Ns1) and T2 (Ns2).

One of the main nutrients responsible for plant growth is nitrogen $(\mathrm{N})$. Restriction of this nutrient reduces growth, as it is part of the structure of amino acids, proteins, nucleic acids, enzymes, vitamins, photosynthetic pigments and their by-products. Nitrogen also plays a part in such processes as ionic absorption, respiration, and cell multiplication and differentiation (Barlog et al., 2017). Irrespective of the treatment, it was found that $\mathrm{N}$ and $\mathrm{K}$ are the most necessary nutrients during the initial growth and development phase of 'Okinawa Roxo' plants (Table 4).

According to Souza et al. (2015), the ideal range for total N content in peach seedlings is from 509.94 to 617.24 $\left(\mathrm{mg} \mathrm{plant}^{-1}\right.$ ), which agrees with the present research. Perennial fruit species of the genus Prunus, such as the peach tree [Prunus persica L. (Basthc)], accumulate $\mathrm{N}$ in the form of free proteins or amino acids, as well as non-structural carbohydrates that include starch and soluble sugars (sucrose, glucose, fructose and sorbitol) (Haider et al., 2018). Such molecules play an essential role in vegetative growth, providing structural components for the formation of new cells and consequently maximum biomass production.

As regards the total phosphorus (P) content, only the plants from treatments T1 (Sn1) and T2 (Sn2) (Table 4) showed values within the range ( $\mathrm{P}=49.53$ to $69.61 \mathrm{mg} \mathrm{plant}^{-1}$ ) considered suitable for the crop (Souza et al., 2015). An adequate $P$ content is fundamental to plant metabolism, allowing rapid and intense root growth (Ullah et al., 2017; Laakso et al., 2017), especially due to its low mobility and its functional importance, where it participates in the formation and integrity of the cell membranes involved in the production and transfer of cellular energy involving ATP, as well as in the metabolism of carbohydrates (Buchanan et al., 2000).

In the production of plants on a commercial scale, a well-formed root system favours the uptake of nutrients and water, providing better plant development when transplanted to the field (Cabeza et al., 2017; Shen et al., 2016). Considering the importance of the roots in fixing and supporting the plants, the information available in the literature on biomass production and the nutritional aspects of the root system in the peach tree are scarce (Mayer et al., 2015).

With respect to the quality of the root system in the commercial substrate (T3), the roots were more fragile, breaking easily when removed from the substrate for chemical analysis of the macro- and micronutrients. This can be attributed to insufficient levels of the nutrients $\mathrm{P}, \mathrm{K}$ and $\mathrm{Ca}$ in the plants from $\mathrm{T} 3$ affecting the quality and 
development of new roots (Higuchi \& Hara, 2017). The deficiency of such nutrients as Ca may present serious restrictions to root development, since this nutrient has limited internal redistribution due to its low mobility (Vliet \& Giller, 2017).

Ca was the third most-accumulated nutrient in the 'Okinawa Roxo' plants, with a maximum content of $94.04 \mathrm{mg}$ plant $^{-1}$ in the shoots and $51.64 \mathrm{mg} \mathrm{plant}^{-1}$ in the roots (Table 4). The accumulated Ca content in the plants from T1 (Ns1) was greater than in the other treatments at 90 DAT, with accumulation values $21.10 \%$ greater in the shoots and $46.04 \%$ in the roots compared to the plants from T2 (Ns2) (Table 4); it can be said that the greater accumulation of each nutrient is due to the higher concentration of nutrients in Ns1 in relation to Ns2 (Table 2) and to the high uptake of $\mathrm{Ca}$ by the crop.

$\mathrm{Ca}$ is strongly related to the integrity of the membranes and cell walls, and to root growth (Vliet \& Giller, 2017). It also acts as a secondary messenger, integrating the complex system for transducing the signals initiated by the binding of plant hormones to their receptors (Silva et al., 2017). Among the most common calcium-binding proteins are calmodulin and the calcium-dependent protein kinases (Vliet \& Giller, 2017).

It is also worth noting that $\mathrm{Ca}$ and $\mathrm{Mg}$ are the activators of several enzymes, some of them related to the absorption of other nutrients; an example is $\mathrm{Mg}$, which activates the enzymes (ATPases) that act in the formation of $\mathrm{H}^{+}$gradients, directly influencing the transport of phosphorus and other nutrients into the cells (Xiong et al., 2015), as well as transport in and out of the vacuole. A fundamental difference between these nutrients is their mobility within the plant. Whereas $\mathrm{Mg}$ can be easily translocated via the phloem, $\mathrm{Ca}$ is an element with low mobility in the plant (Marles, 2017). The Mg absorbed by the roots and accumulated in the shoots can be remobilised to meet the nutritional needs of younger tissue, when its availability in the rhizosphere is reduced (Singh et al., 2016).

In this respect, it can be shown that the Mg content in the plants from T1 (Ns1) was greater than in the other treatments (Table 4), with accumulation values $38.26 \%$ higher in the shoots and $49.76 \%$ in the roots in relation to T2 (Ns2). Furthermore, the Mg content in treatments T2, T3 and T4 did not meet the ideal range (142.0 mg plant $^{-1}$ ) for the peach plants (Souza et al., 2015). According to Rigon et al. (2012), an adequate Mg content contributes to high photosynthetic rates and consequently better plant adaptation when planting in the field.

There are few studies in the domestic and international literature of the supply of sulphur (S) to peach plants (Bakić et al., 2017; Muhammad et al., 2018; Mayer et al., 2015; Souza et al., 2014). It was found that the S content of the shoots ranged from 0.27 to $28.66 \mathrm{mg} \mathrm{plant}^{-1}$. According to Raij (1991), an adequate S content in the shoots of subtropical fruit, is generally between 10.0 and $40 \mathrm{mg} \mathrm{plant}^{-1}$. In the present study, the $\mathrm{S}$ content was within the range established by Raij (1991), except in T4 (Table 4). S applied in suitable doses can favour better plant growth and development due to its participation in the conversion of non-protein nitrogen into protein nitrogen (Yilmaz \& Gökmen, 2016).

As regards micronutrients, Smiderle et al. (2017) showed that iron $(\mathrm{Fe})$ is the micronutrient most accumulated by plants at the initial growth phase, followed by manganese (Mn). However, under the conditions of the present study, the mean Fe content was within the ideal range (2945.00 to $4292.33 \mu \mathrm{g} \mathrm{plant}^{-1}$ ) for Prunus persica (Souza et al., 2015), except in the plants from T3 and T4, where it was below the ideal range (Table 4). It is known that Fe plays an important role in the activation of enzymes, acting as a prosthetic group (Jucoski et al., 2016). In addition, $\mathrm{Fe}$ catalyses chlorophyll biosynthesis, being one of the enzymes responsible for its formation (Yilmaz \& Gökmen, 2016).

Only the plants from T1 (Sn1) had a $\mathrm{Cu}$ and $\mathrm{Mn}$ content within the range suitable for Prunus persica. The other treatments did not provide an adequate $\mathrm{Cu}$ content for the peach, as per Souza et al. (2015).

The highest zinc ( $\mathrm{Zn}$ ) content was detected in the shoots of the 'Okinawa Roxo' plants, at more than $80 \%$ of the total accumulated in the plant (Table 4). Despite the importance of $\mathrm{Zn}$ to crops in general (Mehraj et al., 2017; Wasaya et al., 2017), there is little information in the literature on the use of this micronutrient in the production of peach rootstocks. When applied in suitable doses, in addition to maintaining the structural integrity of the cell membrane (Tiecher et al., 2017), Zn can favour the production of vigorous plants (Hidoto et al., 2017) due to its direct participation in the synthesis of the amino acid, tryptophan, the precursor of indoleacetic acid (IAA), a plant growth regulator related to cell growth and stretching.

Distinct plant responses for nutrient-uptake efficiency were seen in relation to the treatments (Table 5), with the maximum values for uptake efficiency of the macro- and micronutrients recorded in the plants from T1 (Table 5). The smallest values for macro- and micronutrients were seen in T4, and can be explained by the lack or even absence of nutrients essential for the growth and development of the plants during cultivation, as it is an inert 
substrate. When nutrient concentrations are low, or nutrients are unavailable, plants tend to reduce their uptake, even though they may be able to extract them from the substrate and use them more efficiently (Schiattone et al., 2017).

Table 5. Absorption efficiency in 'Okinawa Roxo' rootstock under different forms of cultivation, at 90 days after transplanting

\begin{tabular}{|c|c|c|c|c|c|c|c|c|c|c|c|}
\hline Treatment & $\mathrm{N}$ & $\mathrm{P}$ & $\mathrm{K}$ & $\mathrm{Ca}$ & $\mathrm{Mg}$ & $\mathrm{S}$ & $\mathrm{B}$ & $\mathrm{Cu}$ & $\mathrm{Fe}$ & $\mathrm{Mn}$ & $\mathrm{Zn}$ \\
\hline \multicolumn{12}{|c|}{ Absorption efficiency* } \\
\hline & \multicolumn{6}{|c|}{------------- mg nutrient/g root dry weight ------------ } & \multicolumn{5}{|c|}{-------- $\mu \mathrm{g}$ nutrient/g root dry weight --------- } \\
\hline $\mathrm{T} 1(\mathrm{Sn} 1)$ & $30.43 \mathrm{a}$ & $3.35 \mathrm{a}$ & $24.04 \mathrm{a}$ & $7.18 \mathrm{a}$ & $6.91 \mathrm{a}$ & $2.37 \mathrm{a}$ & $38.07 \mathrm{a}$ & $4.37 \mathrm{a}$ & $241.05 \mathrm{a}$ & $43.86 \mathrm{a}$ & $23.92 \mathrm{a}$ \\
\hline $\mathrm{T} 2(\mathrm{Sn} 2)$ & $27.42 b$ & $2.95 b$ & $20.57 b$ & $6.07 \mathrm{~b}$ & $4.76 b$ & $1.52 b$ & $29.79 b$ & $3.29 b$ & $184.26 b$ & $35.00 \mathrm{~b}$ & $13.97 \mathrm{~b}$ \\
\hline $\mathrm{T} 3$ & $26.89 b$ & $3.07 \mathrm{a}$ & $23.42 \mathrm{a}$ & $2.45 \mathrm{c}$ & $3.32 b$ & $0.93 \mathrm{c}$ & $14.47 \mathrm{c}$ & $2.07 \mathrm{c}$ & $62.24 \mathrm{c}$ & $7.50 \mathrm{c}$ & $15.56 \mathrm{~b}$ \\
\hline $\mathrm{T} 4$ & $3.15 \mathrm{c}$ & $2.45 b$ & $2.34 \mathrm{c}$ & $1.14 \mathrm{~d}$ & $0.90 \mathrm{c}$ & $0.91 \mathrm{c}$ & $0.84 \mathrm{~d}$ & $0.53 \mathrm{~d}$ & $0.23 \mathrm{~d}$ & $0.66 \mathrm{~d}$ & $0.35 \mathrm{c}$ \\
\hline$* \mathrm{CV}(\%)$ & 9.62 & 6.23 & 4.72 & 3.31 & 3.89 & 4.02 & 12.3 & 8.56 & 12.99 & 9.52 & 7.45 \\
\hline \multicolumn{12}{|c|}{ Transport efficiency** } \\
\hline $\mathrm{T} 1(\mathrm{Sn} 1)$ & $67.10 \mathrm{a}$ & $67.31 \mathrm{a}$ & $67.03 \mathrm{a}$ & 65. & $59.13 \mathrm{a}$ & $59.67 \mathrm{a}$ & $0 \mathrm{a}$ & $57.26 \mathrm{~b}$ & 56. & $74.90 \mathrm{a}$ & $88.71 \mathrm{a}$ \\
\hline $\mathrm{T} 2(\mathrm{Sn} 2)$ & $67.18 \mathrm{a}$ & $72.34 \mathrm{a}$ & $70.05 \mathrm{a}$ & $72.70 \mathrm{a}$ & $64.00 \mathrm{a}$ & $65.74 \mathrm{a}$ & $68.28 \mathrm{a}$ & $61.62 b$ & $58.33 \mathrm{a}$ & $64.16 \mathrm{a}$ & $83.80 \mathrm{a}$ \\
\hline $\mathrm{T} 3$ & $68.20 \mathrm{a}$ & $63.20 \mathrm{~b}$ & $71.72 \mathrm{a}$ & $57.09 \mathrm{~b}$ & $66.82 \mathrm{a}$ & $66.47 \mathrm{a}$ & $61.34 \mathrm{~b}$ & $71.52 \mathrm{a}$ & $61.53 \mathrm{a}$ & $55.70 \mathrm{~b}$ & $86.13 \mathrm{a}$ \\
\hline $\mathrm{T} 4$ & $36.82 b$ & $45.39 \mathrm{c}$ & $29.24 b$ & $45.45 \mathrm{c}$ & $45.58 \mathrm{~b}$ & $18.12 \mathrm{~b}$ & $4.09 \mathrm{c}$ & $71.26 \mathrm{a}$ & $39.47 \mathrm{c}$ & $23.15 \mathrm{c}$ & $62.06 \mathrm{~b}$ \\
\hline$* * C V(\%)$ & 14.17 & 12.9 & 13.82 & 13.45 & 13.7 & 13.4 & 14.14 & 13.2 & 13.74 & 13.86 & 13.97 \\
\hline \multicolumn{12}{|c|}{ Use efficiency*** } \\
\hline & \multicolumn{6}{|c|}{-------- $\left(\right.$ dry weight) ${ }^{2} \mathrm{~g} / \mathrm{mg}$ accumulated nutrient -------- } & \multicolumn{5}{|c|}{--- $(\text { dry weight })^{2} \mathrm{~g} / \mu \mathrm{g}$ accumulated nutrient ---- } \\
\hline $\mathrm{T} 1(\mathrm{Sn} 1)$ & $8.92 \mathrm{a}$ & $81.01 \mathrm{a}$ & $11.60 \mathrm{a}$ & $37.81 \mathrm{a}$ & $39.19 \mathrm{a}$ & $114.69 \mathrm{c}$ & $7.14 \mathrm{c}$ & $62.17 \mathrm{a}$ & $1.13 \mathrm{c}$ & $6.19 b$ & $11.36 \mathrm{~b}$ \\
\hline $\mathrm{T} 2(\mathrm{Sn} 2)$ & $7.05 \mathrm{~b}$ & $70.00 \mathrm{~b}$ & $9.98 b$ & $34.10 \mathrm{~b}$ & $43.51 \mathrm{a}$ & $135.77 b$ & $6.95 \mathrm{c}$ & $62.88 \mathrm{a}$ & $1.12 \mathrm{c}$ & $5.91 \mathrm{~b}$ & $14.82 \mathrm{~b}$ \\
\hline $\mathrm{T} 3$ & $5.28 \mathrm{c}$ & $46.22 \mathrm{c}$ & $6.07 \mathrm{c}$ & $17.96 \mathrm{c}$ & $42.85 a$ & $152.82 \mathrm{a}$ & $9.82 b$ & $68.66 \mathrm{a}$ & $2.28 b$ & $18.94 \mathrm{a}$ & $9.13 b$ \\
\hline $\mathrm{T} 4$ & $3.95 \mathrm{~d}$ & $5.09 \mathrm{~d}$ & $5.03 \mathrm{c}$ & $10.93 d$ & $13.90 \mathrm{~b}$ & $13.71 \mathrm{~d}$ & $14.80 \mathrm{a}$ & $23.48 \mathrm{~b}$ & $57.36 \mathrm{a}$ & $18.92 \mathrm{a}$ & $35.22 \mathrm{a}$ \\
\hline$* * * C V(\%)$ & 6.23 & 5.59 & 6.89 & 8.76 & 5.01 & 8.97 & 4.12 & 5.21 & 7.41 & 3.69 & 7.41 \\
\hline
\end{tabular}

Note. Mean values followed by the same letter in a column do not differ by Tukey's test (p $\leq 5 \%)$. **T1 (Ns1); T2 (Ns2); T3 (Commercial Substrate + Water); T4 (Sand + Water). Where: $\mathrm{N}=$ nitrogen; $\mathrm{P}=$ phosphorus; $\mathrm{K}=$ potassium; $\mathrm{Ca}=$ calcium; $\mathrm{Mg}=$ magnesium; $\mathrm{S}=$ sulphur; $\mathrm{B}=$ boron; $\mathrm{Cu}=$ copper; $\mathrm{Fe}=$ iron; $\mathrm{Mn}=$ manganese; $\mathrm{Zn}=$ zinc.

As it is a genetically controlled factor, the nutritional efficiency of a given species and/or genotype can be an aid to breeding programs through which it is possible to select species with a greater capacity to absorb and transport nutrients when under limiting conditions for growth (Rosolem et al., 2017; Retamal-Salgado et al., 2017).

Transport efficiency is an indication of the ability of the plant to transport nutrients from the roots to the shoots and incorporate the absorbed nutrient into the biomass (Xavier \& Natale, 2017). Under the conditions of the present study, the nutrient solutions of $\mathrm{T} 1(\mathrm{Sn} 1)$ and T2 (Sn2) were most suitable for the genetic potential of the 'Okinawa Roxo' plants, showing similar nutrient transport efficiency, greater than seen in the plants from T3 and T4 (Table 5).

Therefore, optimising nutritional efficiency is of great importance, since in general, fertilisers contribute approximately $30 \%$ to the total cost of seedling production (Marles, 2017). Currently in Brazil, few studies characterise plants as to nutrient use efficiency; the few results available in the domestic and international literature refer mainly to cereal production (Beche et al., 2014).

For stone-fruit trees, just as in the production of peach rootstocks, there are no studies on the use efficiency of nutrients from nutrient solutions or substrates. In general, plants of the 'Okinawa Roxo' cultivar from T1 (Ns1) were more efficient in the use of $\mathrm{N}, \mathrm{P}, \mathrm{K}$ and $\mathrm{Ca}$, which can be attributed to a number of factors, such as the higher concentration of nutrients in $\mathrm{T} 1$ (Ns1) (Table 2) and by the formation of ion pairs between the Ca and nitrate $\left(\mathrm{NO}_{3}^{-}\right)$.

The higher nitrate content contributes to the dynamics of the cationic nutrients in the soil, since the $\mathrm{NO}_{3}{ }^{-}$anion is considered an accompanying ion of $\mathrm{Ca}_{2}^{+}, \mathrm{Mg}_{2}^{+}, \mathrm{K}^{+}$and $\mathrm{Al}_{3}^{+}$(Marles, 2017) and thus may improve the 
absorption and use of these nutrients, the results of which can be seen in the morphometric characteristics of the plants, such as a greater investment in shoot growth, and early grafting, as recorded in the present study.

This relationship between canopy growth and N, K and Ca use efficiency was also seen by Xavier and Natalle (2017), where uptake efficiency was the most important parameter in explaining variations in total dry weight production in rootstock of the starfruit (Averrhoa carambola L.).

From the results of the present study, it could be inferred that there was no significant difference in micronutrient use efficiency between $\mathrm{Sn} 1$ and $\mathrm{Sn} 2$, this fact demonstrates the involvement of such micronutrients as $\mathrm{Cu}, \mathrm{Mn}$ and $\mathrm{Fe}$ in electron transport during photosynthesis, on the greater growth in height of the plants.

In order to carry out photosynthesis, superior plants depend on light absorption and the significant presence of carotenoids and chlorophylls $\mathrm{a}$ and $\mathrm{b}$ in the leaves to control carbohydrate metabolism in the chloroplast and cytosol via the chemicals ATP and NADPH (Falqueto et al., 2017). Chlorophylls are related to the photosynthetic efficiency of plants, and consequently to their growth and adaptability to different forms of cultivation (Rigon et al., 2012).

For the variables, chlorophyll a and $\mathrm{b}$ and total chlorophyll, it should be pointed out that the 'Okinawa Roxo' plants from T1 (Ns1) showed an increase of $28.43 \%$ in total chlorophyll content in relation to T2 (Ns2), and $55.0 \%$ in relation to the plants from T4, despite being a cultivar with red leaves (Table 6). It should be noted that the plants from $\mathrm{T} 1$ and $\mathrm{T} 2$ had the highest values for $\mathrm{N}$ concentration $([\mathrm{N}])$, Nitrogen Balance Index (NBI), chlorophyll index (CHLI), chlorophyll $a(\mathrm{CHLa}, \mu \mathrm{g} / \mathrm{mL})$, chlorophyll $b(\mathrm{CHLb}, \mu \mathrm{g} / \mathrm{mL})$ and total chlorophyll (CHLT $\mu \mathrm{g} / \mathrm{mL}$ ), when compared to T3 and T4, with all the treatments being different (Table 6).

Table 6. Mean values for nitrogen balance index (NBI), nitrogen concentration ([N]), chlorophyll index (CHLI), chlorophyll $a(\mathrm{CHL} a, \mu \mathrm{g} / \mathrm{mL})$, chlorophyll $b(\mathrm{CHL} b, \mu \mathrm{g} / \mathrm{mL})$ and total chlorophyll (CHLT $\mu \mathrm{g} / \mathrm{mL})$ in 'Okinawa Roxo' rootstocks under different forms of cultivation, at 90 days

\begin{tabular}{lllllll}
\hline Treatment & NBI & {$[\mathrm{N}]$} & CHLI & CHL $a$ & CHL $b$ & CHLT \\
\hline T1 (Ns1)** & $32.18 \mathrm{a}^{*}$ & $30.82 \mathrm{a}$ & $31.12 \mathrm{a}$ & $20.55 \mathrm{a}$ & $11.21 \mathrm{a}$ & $31.76 \mathrm{a}$ \\
T2 $(\mathrm{Ns} 2)$ & $26.67 \mathrm{~b}$ & $24.31 \mathrm{~b}$ & $24.67 \mathrm{~b}$ & $15.48 \mathrm{~b}$ & $7.25 \mathrm{~b}$ & $22.73 \mathrm{~b}$ \\
T3 & $18.00 \mathrm{c}$ & $16.03 \mathrm{c}$ & $17.09 \mathrm{c}$ & $10.89 \mathrm{c}$ & $6.62 \mathrm{c}$ & $17.51 \mathrm{c}$ \\
T4 & $10.11 \mathrm{~d}$ & $8.02 \mathrm{~d}$ & $9.48 \mathrm{~d}$ & $5.10 \mathrm{~d}$ & $3.15 \mathrm{~d}$ & $8.25 \mathrm{~d}$ \\
\hline Mean & 21.74 & 19.79 & 20.59 & 13.05 & 7.05 & 20.06 \\
\hline CV $(\%)$ & 6.06 & 7.09 & 6.80 & 3.77 & 3.83 & 3.92 \\
\hline
\end{tabular}

Note. *Mean values followed by the same letter in a column do not differ by Tukey's test ( $\mathrm{p} \leq 5 \%) .{ }^{* *} \mathrm{~T} 1(\mathrm{Sn} 1)$; T2 (Sn2); T3 (Commercial Substrate + Water); T4 (Sand + Water).

Positive correlations were found for the variables associated with the levels of chlorophyll and N, ranging from moderate to high magnitude (Table 7). According to Souza et al. (2016), a correlation is considered of high magnitude when the correlation coefficient ranges from $0.8 \leq \mathrm{r}<1.0$. Positive correlations of high magnitude were obtained between the CHLI and the CHLT content of the leaves of the 'Okinawa Roxo' plants. The same occurred between the NBI and $[\mathrm{N}]$ in the leaves, showing that non-destructive measurement using a chlorophyll meter gives an excellent estimation of these variables, since a high correlation was also obtained between $[\mathrm{N}]$ and CHLI.

Table 7. Correlation matrix for the Pearson coefficients* between the variables, nitrogen balance index (NBI), nitrogen concentration ([N]), chlorophyll index (CHLI), chlorophyll $a(\mathrm{CHL} a, \mu \mathrm{g} / \mathrm{mL})$, chlorophyll $b(\mathrm{CHL} b$, $\mu \mathrm{g} / \mathrm{mL}$ ) and total chlorophyll (CHLT $\mu \mathrm{g} / \mathrm{mL}$ ) in 'Okinawa Roxo' rootstocks under different forms of cultivation, at 90 days

\begin{tabular}{llllll}
\hline Variable & CHLI & CHL $a$ & CHL $b$ & CHLT & {$[\mathrm{N}]$} \\
\hline NBI & $0.98^{*}$ & $0.89^{*}$ & $0.85^{*}$ & $0.96^{*}$ & $0.99^{*}$ \\
CHLI & - & $0.86^{*}$ & $0.79^{*}$ & $0.99^{*}$ & $0.97^{*}$ \\
CHL $a$ & - & - & $0.84^{*}$ & $0.86^{*}$ & $0.76^{*}$ \\
CHL $b$ & - & - & - & $0.71^{*}$ & $0.71^{*}$ \\
CHLT & - & - & - & - & $0.97^{*}$ \\
{$[$ N $]$} & - & - & - & - & - \\
\hline
\end{tabular}


These estimates corroborate the usefulness of the chlorophyll meter as a tool for estimating or diagnosing the nutritional status of various crops (Xiong et al., 2015), for example, the results obtained with nectarine plants (Takle et al., 2017), peach trees (Souza et al., 2017) and apple trees (Tamburini et al., 2015).

$[\mathrm{N}]$ was positively correlated with the total chlorophyll content, showing that this can act as an indicator of $[\mathrm{N}]$ in the leaves of the peach, and making it possible to detect $\mathrm{N}$ deficiency earlier, even in the case of red-coloured leaves. A positive correlation of high magnitude was found between NBI and CHLI, which is mainly due to the fact that $50 \%$ to $75 \%$ of the $\mathrm{N}$ is present in cells of the mesophile associated with nitrite reductase enzymes (NR) in the chloroplasts (Singh et al., 2016). According to Gitelson et al. (2016), this enzyme is considered the key in regulating $\mathrm{N}$ metabolism, since the nitrate absorbed by the roots must be reduced to $\mathrm{NH}_{4}{ }^{+}$before being incorporated into organic compounds in the shoots and/or root system.

In the present study, the correlations of moderate to high magnitude between these variables are of great importance for establishing a standard to aid in early $\mathrm{N}$ diagnosis, thereby allowing timely decision-making for possible $\mathrm{N}$ fertilisation. For this reason, the chlorophyll meter proved to be a suitable tool for use in precision agriculture.

In general, the results of the present study showed that adequate nutrition during the stage of rapid plant growth is important to allow the satisfactory physiological performance of the plants. As the plant is intended for grafting, it could be demonstrated that, even using inert or partially inert substrates such as sand, it is possible to have a growth pattern good enough for early grafting when using suitable nutrient solutions.

This implies a reduction in the time plants spend in the nursery, reducing production costs, an important characteristic for the production sector of stone-fruit rootstock. Considering that in the domestic and international literature there is no information on the mechanisms of uptake, translocation, remobilisation or nutrient use efficiency in the 'Okinawa Roxo' rootstock, the present study represents an important contribution of information as an aid in the nutritional management of the peach during seedling production.

\section{Conclusions}

Commercial substrate without the addition of nutrients is not indicated for the production of 'Okinawa Roxo' rootstock in plastic bags in a greenhouse.

The nutrient solutions Ns1 and Ns2 make it possible to obtain 'Okinawa Roxo' plants of excellent morphophysiological and nutritional characteristics, that are suitable for grafting three months after transplanting in a greenhouse.

The best absorption efficiency of macro- and micronutrients by 'Okinawa Roxo' rootstock is when using the Ns1 nutrient solution.

Use of the chlorophyll meter allows an adequate estimation of the nitrogen and total chlorophyll content in the red-leaved peach tree, and is a precise tool for indicating the nutritional state of the plant.

\section{References}

Abrisqueta, I., Quezada-Martin, R., Munguía-López, J. P., Ruiz-Sánchez, M. C., Abrisqueta, J. M., \& Vera, J. (2011). Nutrient concentrations of peach-tree leaves under deficit irrigation. Journal of Plant Nutrition and Soil Science, 174, 871-873. https://doi.org/10.1002/jpln.201100116

Albornoz, F., Lieth, J. H., \& González-Fuentes, J. A. (2014). Effect of different day and night nutrient solution concentrations on growth, photosynthesis, and leaf $\mathrm{NO}_{3}{ }^{-}$content of aeroponically grown lettuce. Chilean Journal of Agricultural Research, 74, 240-245. https://doi.org/10.4067/S0718-58392014000200017

American Psychological Association. (1972). Ethical standards of psychologists. Washington, DC: American Psychological Association.

Arnon, D. I. (1949). Copper enzymes in isolated chloroplasts: Polyphenoloxydase in Beta vulgaris. Plant Physiology, 24, 1-15. https://doi.org/10.1104/pp.24.1.1

Bakić, I. V., Rakonjac, V. S., Čolić, S. D., Akšić, M. M. F., Nikolić, D. T., Radović, A. R., \& Rahović, D. D. (2017). Agro-morphological characterisation and evaluation of a Serbian vineyard peach [Prunus persica (L.) Batsch] germplasm collection. Scientia Horticulturae, 225, 668-675. https://doi.org/10.1016/ j.scienta.2017.07.036

Baldi, E., Marcolini, G., Quartieri, M., Sorrenti, G., \& Toselli, M. (2014). Effect of organic fertilization on nutrient concentration and accumulation in nectarine (Prunus persica var. nucipersica) trees: The effect of rate of application. Scientia Horticulturae, 179, 174-179. https://doi.org/10.1016/j.scienta.2014.09.029 
Bataglia, O. C., Furlani, A. M. C., Teixeira, J. P. F., Furlani, P. R., \& Gallo, J. R. (1983). Métodos de análise química de plantas. Campinas: Instituto Agronômico.

Beche, E., Benin, G., Bornhofen, E., Dalló, S. C., Sassi, L. H. S., Oliveira, R. (2014). Eficiência de uso de nitrogênio em cultivares de trigo pioneiras e modernas. Pesquisa Agropecuária Brasileira, 49, 948-957. https://doi.org/10.1590/S0100-204X2014001200005

Brasil, Ministério da Agricultura, Pecuária e Abastecimento. (2005). Portaria No 37-anexo-XIV, de 16 de dezembro de 2005. Normas e padrões específicos para a produção, comercialização e utilização de mudas de pessegueiro (Prunus persica (L.) Batsch), nectarineira (Prunus persica (L.) Batsch var. nucipersica) $e$ ameixeira (Prunus domestica L.). Brasília, Brazil.

Brazilian Fruit Yearbook. (2017). Panorama. Editora Gazeta. Retrieved from http://www.editoragazeta.com.br/ sitewp/wp-content/uploads/2017/03/PDF-Fruticultura_2017.pdf

Buchanan, B. B., Gruissem, W., \& Jones, R. L. (2000). Biochemistry \& Molecular Biology of Plants (p. 1367). Rockville: American Society of Plant Biologists.

Cabeza, R. A., Myint, K., Steingrobe, B.; Stritsis, C., Schulze, J., \& Claassen, N. (2017). Phosphorus fractions depletion in the rhizosphere of young and adult maize and oilseed rape plants. Journal of Soil Science and Plant Nutrition, 17, 824-838. https://doi.org/10.4067/S0718-95162017000300020

Dickson, A., Lead, A. L., \& Osmer, J. F. (1960). Quality appraisal of white spruce and white pine seedling stock in nurseries. Forestry chronicle, 36, 10-13. https://doi.org/10.5558/tfc36237-3

Elsadr, H. T., \& Sherif, S. (2016). Peaches and Nectarines. Encyclopedia of Food and Health, 122, $270-276$. https://doi.org/10.1016/B978-0-12-384947-2.00527-4

Falqueto, A. R., Junior, R. A. S., Gomes, M. T. G., Martins, J. P. R., Silva, D. M. S., \& Partelli, F. L. (2017). Effects of drought stress on chlorophyll a fluorescence in two rubber tree clones. Scientia Horticulturae, 224, 238-243. https://doi.org/10.1016/j.scienta.2017.06.019

Ferreira, D. F. (2011). Sisvar: A computer statistical analysis system. Ciência e Agrotecnologia, 35, $1039-1042$. https://doi.org/10.1590/S1413-70542011000600001

Fiorini, I. V. A., Von Pinho, R. G., Pereira, H. D., Pires, L. P. M., Fiorini, F. V. A., \& Resende, E. L. (2017) Acúmulo de matéria seca, clorofila e enxofre foliar em milho adubado com diferentes fontes de enxofre. Journal of Bioenergy and Food Science, 4, 1-11.

Fischer, D. L. O., Picolotto, L., Rocha, M. S., Souza, A. G., \& Bianchi, V. J. (2016). Influência do período de estratificação em frio úmido sobre a emergência e produção de porta-enxertos de pessegueiro a campo. Revista Congrega, 1, 1-11.

Gitelson, A. A., Peng, Y., Vina, A., Arkebauer, T., \& Schepers, J. S. (2016). Efficiency of chlorophyll in gross primary productivity: A proof of concept and application in crops. Journal Plant Physiological, 201, 101-110. https://doi.org/10.1016/j.jplph.2016.05.019

Granatstein, D., Kirby, E., Ostenson, H., \& Willer, H. (2016). Global situation for organic tree fruits. Scientia Horticulturae, 208, 3-12. https://doi.org/10.1016/j.scienta.2015.12.008

Haider, M. S., Kurjogi, M. M., Khalil-urRehman M., Kurjogi, M. M., Pervez, M. M., Songtao J., ... Fang J. (2018). Drought stress revealed physiological, biochemical and gene-expressional variations in 'Yoshihime' peach (Prunus Persica L.) cultivar. Journal of Plant Interactions, 13, 83-90. https://doi.org/10.1080/ 17429145.2018 .1432772

Hidoto, L., Worku, W., Mohammed, H., \& Bunyamin, T. (2017). Effects of zinc application strategy on zinc content and productivity of chickpea grown under zinc deficient soils. Journal of Soil Science and Plant Nutrition, 17, 112-126. https://doi.org/10.4067/S0718-95162017005000009

Higuchi, K., \& Hara, K. (2017). Common reed absorbs $\mathrm{K}^{+}$more selectively than rice against high $\mathrm{Na}^{+} / \mathrm{K}^{+}$ratio in nutrient solution. Soil Science and Plant Nutrition, 3, 483-487. https://doi.org/10.1080/00380768.2017. 1381573

Jucoski, G. O., Cambraia, J., Ribeiro, C., \& Oliveira, J. A. (2016). Excesso de ferro sobre o crescimento e a composição mineral em Eugenia uniflora L. Revista Ciência Agronômica, 47, 720-728. https://doi.org/ $10.5935 / 1806-6690.20160086$ 
Li, B., McKeand, S. E., \& Allen, H. L. (1991). Genetic variation in nitrogen use efficiency of loblolly pine seedlings. Forest Science, 37, 613-626.

Marles, R. J. (2017). Mineral nutrient composition of vegetables, fruits and grains: The context of reports of apparent historical declines. J. F. Comp. Ana., 56, 93-103. https://doi.org/10.1016/j.jfca.2016.11.012

Mayer, N. A., Bianchi, V. J., Feldberg, N. P., \& Morini, S. (2017). Advances in peach, nectarine and plum propagation. Revista Brasileira de Fruticultura, 39, 1-21. https://doi.org/10.1590/0100-29452017355

Mayer, N. A., Ueno, B., \& Silva, V. A. L. (2015). Teores de nutrientes foliares de pessegueiro em cinco porta-enxertos. Revista Brasileira de Fruticultura, 37, 1045-1052. https://doi.org/10.1590/01002945-197/14

Mayer, N., Picolotto, L., Bastos, P. V., Ueno, B., Antunes, L. E. C. (2014). Estaquia herbácea de porta-enxertos de pessegueiro no final do verão. Semina: Ciências Agrárias, 35, 1761-1772. https://doi.org/10.5433/ 1679-0359.2014v35n4p1761

Mehraj, H., Nishimura, Y., \& Shimasaki, K. (2017). Analysis of essential macro-micro mineral content of twelve hosta taxa. Annals of Agricultural Sciences, 62, 71-74. https://doi.org/10.1016/j.aoas.2017.05.001

Meriño-Gergichevich, C., Reyes-Díaz, M., Guerrero, J., \& Ondrasek, G. (2017). Physiological and nutritional responses in two highbush blueberry cultivars exposed to deficiency and excess of boron. Journal of Soil Science and Plant Nutrition, 17, 307-318.

Miloševic, T., Miloševic, N., \& Glisic, I. (2013). Agronomic properties and nutritional status of plum trees (Prunus domestica L.) influenced by different cultivars. Journal Soil Science Plant Nutrition, 13, 706-714. https://doi.org/10.4067/S0718-95162013005000056

Muhammad, A., Sanden, B. L., Sebastian, S., Bruce, D. L., \& Patrick, H. B. (2018). Optimization of nitrogen and potassium nutrition to improve yield and yield parameters of irrigated almond (Prunus dulcis (Mill.) D. A. webb). Scientia Horticulturae, 228, 204-212. https://doi.org/10.1016/j.scienta.2017.10.024

Pereira, F. M., \& Kavati, R. (2011). Contribuição da pesquisa científica brasileira no desenvolvimento de algumas frutíferas de clima subtropical. Revista Brasileira de Fruticultura, 33, 92-108. https://doi.org/ $10.1590 / \mathrm{S} 0100-29452011000500013$

Peticila, A., Scaeteanu, G. V., Madjar, R., Stanica, F., \& Asanica, A. (2015). Fertilization effect on mineral nutrition of Actinidia deliciosa (kiwi) cultivated on different substrates. Agriculture and Agricultural Science, 6, 132-138. https://doi.org/10.1016/j.aaspro.2015.08.049

Picolotto, L., Bianchi, V. J., Gazolla Neto, A., \& Fachinello, J. C. (2007) Diferentes misturas de substratos na formação de mudas de pessegueiro, em embalagem. Scientia Agraria, 8, 119-125. https://doi.org/10.5380/ rsa.v8i 2.8375

Pradeepkumar, T., Binoo, P., Bonny, R., Midhila, J. J., Divya, C. M. R., \& Varun, R. (2017). Effect of organic and inorganic nutrient sources on the yield of selected tropical vegetables. Scientia Horticulturae, 224, 84-92. https://doi.org/10.1016/j.scienta.2017.04.022

R. Development Core Team. (2008). $R$ : A language and environment for statistical computing, reference index version 2.8.0. R Foundation for Statistical Computing, Vienna.

Reeve, J. R., Culumber, C. M., Black, B. L., Tebeau, A., Ransom, C. V., Alston, D. M., \& Rowley, T. L. (2017). Establishing peach trees for organic production in Utah and the Intermountain West. Scientia Horticulturae, 214, 242-251. https://doi.org/10.1016/j.scienta.2016.11.040

Retamal-Salgado, J., Matus, I., Walter, I., \& Hirzel, J. (2017). Absorption and distribution of cadmium of three maize hybrids in three environments. Journal of Soil Science and Plant Nutrition, 17, 266-278. https://doi.org/10.1016/j.scienta.2017.04.022

Rigon, J. P. G., Beltrão, N. E. M., Capuani, S., Neto, J. F. B., \& Silva, F. V. F. (2012). Non destructive analysis of photosynthetic pigments in leaves of Sesamum indicum (L.). Revista Brasileira de Engenharia Agrícola e Ambiental, 16, 258-261. https://doi.org/10.1590/S1415-43662012000300004

Rocha, M. S., Fischer, D. L. O., Fachinello, J. C., Schimitz, J. D., Pasa, M. S., \& Bianchi, V. J. (2016). Propagation of peach rootstocks by watering and survival after field planting, Revista Congrega, 1, 15-22. 
Rosolem, C. A., Ritz, K., Cantarella, H., Galdos, M. V., Hawkesford, M. J., Whalley, W. R., \& Mooney, S. J. (2017). Enhanced plant rooting and crop system management for improved $\mathrm{N}$ use efficiency. Advances in Agronomy, 146, 205-239. https://doi.org/10.1016/bs.agron.2017.07.002

Santos, C. (2010). Estatística descritiva: Manual de auto aprendizagem. Lisboa, Sílabo.

Savvas, D., Öztekin, G. B., Tepecik, M., RopoKis, A., Tuzel, Y., Ntatsi, G., \& Schwarz, D. (2017). Impact of grafting and rootstock on nutrient-to-water uptake ratios during the first month after planting of hydroponically grown tomato. The Journal of Horticultural Science and Biotechnology, 92, 294-302. https://doi.org/10.1080/14620316.2016.1265903

Schiattone, M. I., Viggiani, R., Di Venere, D., Sergio, L., Cantore, V., Todorovic, M., Perniola, M., \& Candido V. (2017). Impact of irrigation regime and nitrogen rate on yield, quality and water use efficiency of wild rocket under greenhouse conditions. Scientia Horticulturae, 229, 182-192. https://doi.org/10.1016/ j.scienta.2017.10.036

Shen, Q., Hedley, M., Camps Arbestain, M., \& Kirschbaum, M. U. F. (2016). Can biochar increase the bioavailability of phosphorus? Journal of Soil Science and Plant Nutrition, 16, 268-286. https://doi.org/ $10.4067 / \mathrm{S} 0718-95162016005000022$

Siddiqi, M. Y., \& Glass, A. D. M. (1981). Utilization index: A modified approach to the estimation and comparison of nutrient efficiency in plants. Journal of Plant Nutrition, 4, 289-302. https://doi.org/10.1080/ 01904168109362919

Silva, D. M., Souza, K. R. D., Vilas Boas, L. V., Alves, Y. S., \& Alves, J. D. (2017). The effect of magnesium nutrition on the antioxidant response of coffee seedlings under heat stress. Scientia Horticulturae, 224, 115-125. https://doi.org/10.1016/j.scienta.2017.04.029

Singh, M., Singh, V. P., \& Prasad, S. M. (2016). Responses of photosynthesis, nitrogen and proline metabolism to salinity stress in Solanum lycopersicum under different levels of nitrogen supplementation. Plant Physiology and Biochemistry, 109, 72-83. https://doi.org/10.1016/j.plaphy.2016.08.021

Smiderle, O. J., Souza, A. G., Pedrozo, C. A., \& Lima, C. G. B. (2017). Nutrient solution and substrates for 'cedro doce' (Pochota fendleri) seedling production. Revista Brasileira de Engenharia Agrícola e Ambiental, 21, 227-231. https://doi.org/10.1590/1807-1929/agriambi.v21n4p227-231

Sommer, J., Michaela, A. D., Heinz, D. F., \& Kuzyakov, Y. (2016). Allocation and dynamics of C and N within plant-soil system of ash and beech. Journal of Plant Nutrition and Soil Science, 179, 376-387. https://doi.org/10.1002/jpln.201500384

Souza, A. G., Chalfun, N. N. J., Faquin, V., \& Souza, A. A. (2011). Production of peach grafts under hydroponic conditions. Ciência e Agrotecnologia, 35, 322-326. https://doi.org/10.1590/S1413-70542011000200013

Souza, A. G., Chalfun, N. N. J., Faquin, V., Souza, A. A., \& Neto, A. L. S. (2015). Dry matter and nutrient accumulation in grafted peach seedlings in hydroponic system. Revista Brasileira de Fruticultura, 37, 240-246. https://doi.org/10.1590/0100-2945-020/14

Souza, A. G., Smiderle, O. J., Spinelli, V. M., Souza, R. O., \& Bianchi, V. B. (2016). Correlation of biometrical characteristics of fruit and seed with twinning and vigor of Prunus persica rootstocks. Journal of Seed Science, 38, 322-328. https://doi.org/10.1590/2317-1545v38n4164650

Souza, A. G., Smiderle, O. J., Spinelli, V. M., Souza, R. O., \& Bianchi, V. B. (2017). Optimization of germination and initial quality of seedlings of Prunus persica tree rootstocks. Journal of Seed Science, 39, 166-173. https://doi.org/10.1590/2317-1545v39n2171687

Sun, Y., Wang, Y., Xiao, H., Gu, X., Pan, L., \& Tu, K. (2017). Hyperspectral imaging detection of decayed honey peaches based on their chlorophyll content. Food Chemistry, 235, 194-202. https://doi.org/10.1016/ j.foodchem.2017.05.064

Swiader, J. M., Chyan, Y., \& Freiji, F.G. (1994). Genotypic differences in nitrate uptake and utilization efficiency in Pumpkin hybrids. Journal of Plant Nutrition, 17, 1687-1699. https://doi.org/10.1080/019041 69409364840

Takle, B., Cochran, D., \& McCabe, K. (2017). Evaluation of peach and nectarine production in high tunnel and field plots. Farm Progress Reports, 30, 16-36. https://doi.org/10.31274/farmprogressreports-180814-1602 
Tamburini, E., Ferrari, G., Marchetti, M. G., Pedrini, P., \& Ferro, S. (2015). Development of FT-NIR models for the simultaneous estimation of chlorophyll and nitrogen content in fresh apple (Malus domestica) leaves. Sensors, 15, 2662-2679. https://doi.org/10.3390/s150202662

Tiecher, T. L., Tiecher, T., Ceretta, C. A., Ferreira, P. A. A., Nicoloso, F. T., Hilda, H., ... Brunetto, G. (2017). Tolerance and translocation of heavy metals in young grapevine (Vitis vinifera) grown in sandy acidic soil with interaction of high doses of copper and zinc. Scientia Horticulturae, 222, 203-212. https://doi.org/ 10.1016/j.scienta.2017.05.026

Ullah, S., Jan, A., Ali, M., Ahmad, A., Ullah, A., Ahmad, G., ... Riaz, A. (2017). Effect of phosphorous and zinc under different application methods on yield attributes of chickpea (Cicer arietinum L.). International Journal of Agricultural and Environmental Research, 3, 79-85.

Vliet, J. A. V., \& Giller, K. E. (2017). Mineral Nutrition of Cocoa: A Review. Advances in Agronomy, 141, 185-270. https://doi.org/10.1016/bs.agron.2016.10.017

Wang, H., Wang, F., Wang, G., \& Majourhat, K. (2007). The responses of photosynthetic capacity, chlorophyll fluorescence and chlorophyll content of nectarine (Prunus persica var. Nectarina Maxim) to greenhouse and field grown conditions. Scientia Horticulturae, 112, 66-72. https://doi.org/10.1016/ j.scienta.2006.12.007

Wasaya, A., Shabir, M. S., Hussain, M., Ansar, M., Aziz, A., Hassan, W., \& Ahmad, I. (2017). Foliar application of Zinc and Boron improved the productivity and net returns of maize grown under rainfed conditions of Pothwar plateau. Journal of Soil Science and Plant Nutrition, 17, 33-45. https://doi.org/10.4067/ S0718-95162017005000003

Xavier, C. V., \& Natale, W. (2017). Influence of boron on the content, accumulation and nutritional efficiency in rootstock of star fruit. Revista Brasileira de Ciências Agrárias, 12, 6-13. https://doi.org/10.5039/ agraria.v12i1a5409

Xiong, D., Chen, J., Yu, T., Gao, W., Ling, X., Li, Y., ... Huang, J. (2015). SPAD-based leaf nitrogen estimation is impacted by environmental factors and crop leaf characteristics. Scientific Reports, 5, 133-141. https://doi.org/10.1038/srep13389

Yilmaz, C., \& Gökmen, V. (2016). Chlorophyll. Encyclopedia of Food and Health, 85, 37-41. https://doi.org/10.1016/B978-0-12-384947-2.00147-1

Zhang, J., Zeng, Li., Sun, H., Wu, H., \& Chen, S. (2017). Adversity stress-related responses at physiological attributes, transcriptional and enzymatic levels after exposure to $\mathrm{Cu}$ in Lycopersicum esculentm seedlings. Scientia Horticulturae, 222, 213-220. https://doi.org/10.1016/j.scienta.2017.05.027

Zhu, W., Liu, J., Ye, J., \& Li, G. (2017). Effects of phytotoxic extracts from peach root bark and benzoic acid on peach seedlings growth, photosynthesis, antioxidance and ultrastructure properties. Scientia Horticulturae, 215, 49-58. https://doi.org/10.1016/j.scienta.2016.12.004

\section{Copyrights}

Copyright for this article is retained by the author(s), with first publication rights granted to the journal.

This is an open-access article distributed under the terms and conditions of the Creative Commons Attribution license (http://creativecommons.org/licenses/by/4.0/). 